\title{
AN EVALUATION OF A NEW DIAGNOSTIC TEST FOR SYSTEMIC LUPUS ERYTHEMATOSUS
}

\author{
BY \\ M. WILKINSON AND E. G. REES \\ From St. Bartholomew's Hospital Medical College and the Pathology Department, \\ St. Bartholomew's Hospital, London
}

(RECEIVED FOR PUBLICATION MARCH 29, 1958)

In a disease with such widespread and variable manifestations as systemic lupus erythematosus the diagnosis, at least in the early stages, often depends upon a clinical suspicion supported by laboratory investigations, notably the demonstration of lupus erythematosus (L.E.) cells. While this test is highly specific for systemic lupus erythematosus it has these disadvantages. In a few patients L.E. cells may not be demonstrable until late in the course of the illness and in a very few cases they may perhaps be absent throughout. The test requires expert interpretation if it is to be reliable.

A really simple screening test that could be applied to the many patients with apparent rheumatoid arthritis, cutaneous lupus erythematosus, rheumatic fever, and other diseases which may be mimicked by systemic lupus erythematosus, would be invaluable for the early diagnosis of this more serious illness.
Recently Jones and Thompson (1957) have described a simple protein precipitation test which they have found useful in the diagnosis of systemic lupus erythematosus and which apparently gives false positive results only in liver diseases and myelomatosis, conditions which do not usually cause clinical confusion with systemic lupus erythematosus.

The present report summarizes experience of this test applied on 1,042 occasions to serum from more than 800 patients with various diseases, including systemic lupus erythematosus and discoid lupus erythematosus. Attempts have also been made to identify the protein fraction precipitated in the test.

\section{Methods}

The test reagent consists of a $12 \%$ solution of paratoluene sulphonic acid in glacial acetic acid. This should give a clear solution which keeps indefinitely. Old discoloured preparations of paratoluene sul-

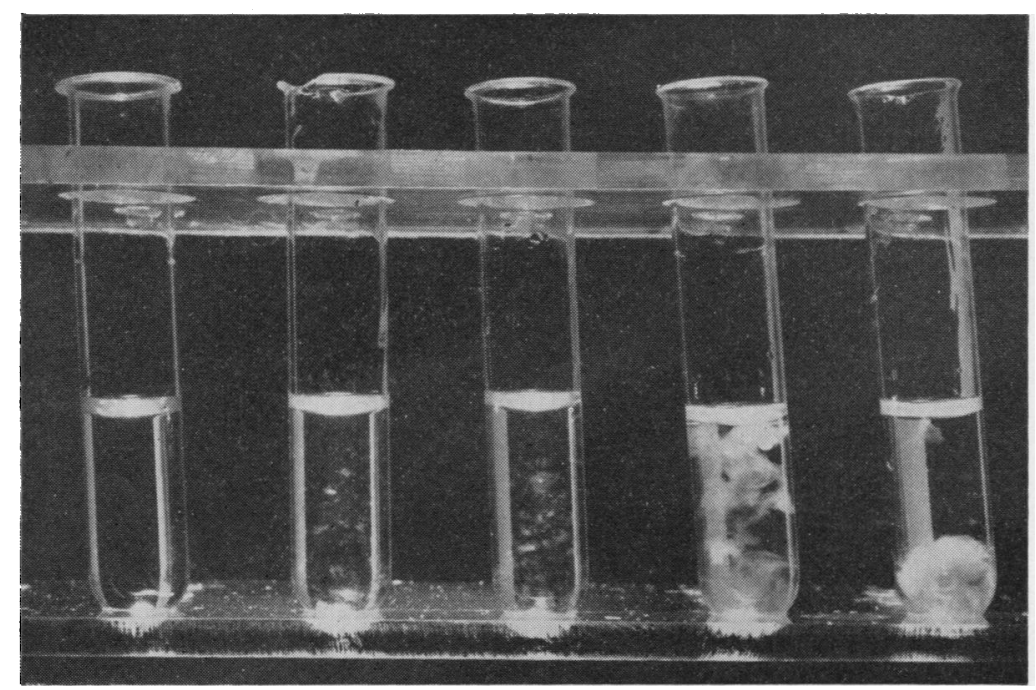

FIG. 1.-Grading of results of paratoluene sulphonic acid tests. Reading from left to right, the above tubes were read as $0, \pm,+,++,+++$. 
phonic acid were found to be unsuitable and caused a high proportion of false positive results. One millilitre of the reagent was pipetted into a small test-tube and to this was added $0.1 \mathrm{ml}$. of serum. In a positive test a precipitate appears at once, but in this series the tubes were left for 20 to 30 minutes, then vigorously shaken and examined for precipitation with indirect lighting against a dark matt background. The degree of precipitation was recorded as shown in Fig. 1.

With plasma instead of serum, precipitation occurred more frequently and rendered the test rather non-specific.

\section{Interpretation}

It soon became obvious that minor degrees of precipitation (either \pm or + ) occurred not infrequently with sera from patients with many diseases. On the other hand most cases of active systemic lupus erythematosus gave ++ or +++ precipitation. This was called "significant precipitation."

\section{Results}

Systemic Lupus Erythematosus.-This group consists of 25 patients who had a clinical picture compatible with the diagnosis of systemic lupus erythematosus and all of whom had shown a positive L.E. cell test at some stage in the illness. Table I shows the results of paratoluene sulphonic acid tests, the intensity of L.E. tests on the same blood samples and the activity of the disease at the time of testing. The last assessment was based

TABLE I

RESULTS OF PARATOLUENE SULPHONIC ACID TESTS ON 25 PATIENTS WITH SYSTEMIC LUPUS ERYTHEMATOSUS CORRELATED WITH THE THERAPY, DISEASE ACTIVITY, AND L.E. TEST AT TIME OF TESTING

\begin{tabular}{|c|c|c|c|c|}
\hline Patient & Therapy & $\begin{array}{l}\text { Disoase } \\
\text { Activity }\end{array}$ & $\begin{array}{l}\text { L.E. } \\
\text { Test }\end{array}$ & $\begin{array}{l}\text { Paratoluene } \\
\text { Sulphonic } \\
\text { Acid Test }\end{array}$ \\
\hline $\begin{array}{ll}\text { E. S. } & \cdots \\
\text { Y.S. } & \cdots \\
\text { G. G. } & \cdots \\
\text { G. Gr. } & \\
\text { A. H. } & \cdots \\
\text { C. M. } & \cdots \\
\text { K. O. } & \cdots \\
\text { P. S. } & \cdots \\
\text { E. B. } & \cdots \\
\text { E. S. } & \cdots \\
\text { K. M. } & \cdots \\
\text { L. L. } & \cdots \\
\text { M. Q. } & \cdots \\
\text { S. M. } & \cdots \\
\text { P. R. } & \cdots \\
\text { E. O. } & \cdots \\
\text { P. Gr. } & \cdots \\
\text { L. B. } & \cdots \\
\text { J. W. } & \cdots \\
\text { Q. J. } & \cdots \\
\text { B. W. } & \cdots \\
\text { B. B. } & \cdots \\
\text { J. W. W. } & \cdots \\
\text { F. T. } & \cdots \\
\text { Ph. L. } & \cdots\end{array}$ & $\begin{array}{c}\text { Nil } \\
\text {,", } \\
\text {," } \\
\text {," } \\
\text {," } \\
\text { ", } \\
\text {," } \\
\text {," } \\
\text { Prednisone } \\
\text { Prednisolone } \\
\text { Prodnisone } \\
\text { Cortisone } \\
\text { Pred̉nisolone } \\
\text { Prednisone } \\
\text { Prednisolone } \\
\text {," }\end{array}$ & $\begin{array}{l}+++ \\
+++ \\
+++ \\
+++ \\
+++ \\
+++ \\
+++ \\
++ \\
++ \\
++ \\
++ \\
+ \\
+ \\
+ \\
0 \\
+++ \\
+++ \\
+++ \\
++ \\
+ \\
+ \\
+ \\
+ \\
+ \\
+\end{array}$ & $\begin{array}{l}+++ \\
+++ \\
+++ \\
++ \\
+++ \\
++ \\
+ \\
+ \\
++ \\
++ \\
++ \\
+ \\
+ \\
+ \\
0 \\
++ \\
+ \\
++ \\
0 \\
0 \\
0 \\
0 \\
0 \\
+ \\
0\end{array}$ & $\begin{array}{l}+++ \\
+++ \\
+++ \\
++ \\
++ \\
++ \\
0 \\
+++ \\
+++ \\
++ \\
++ \\
++ \\
+ \\
+ \\
0 \\
0 \\
0 \\
0 \\
+++ \\
+ \\
0 \\
0 \\
+ \\
0 \\
++\end{array}$ \\
\hline
\end{tabular}

* The disease activity and intensity of the L.E. test are graded from 0 to +++ . on the patients' clinical condition, temperature, and erythrocyte sedimentation rate.

Of 14 patients with active untreated disease, the test gave ++ or +++ precipitation in 11 . With one exception (K. O.) there was fair correlation between the amount of precipitate and the activity of the disease. In two of the patients repeated tests were done before and during treatment and the amount of precipitate found did correspond fairly well with the activity of the disease (Fig. 2).

One patient (P. R.), in whom the disease was in remission and who was no longer on treatment, showed no L.E. cells at the time of testing and the paratoluene sulphonic acid test was negative.

From 10 patients tested for the first time while on steroid therapy, only two sera showed significant precipitation. In these patients the correlation between the amount of precipitate and the disease activity was poor.

Probable Systemic Lupus Erythematosus.Three patients with a very suggestive clinical picture failed to show L.E. cells despite repeated tests. None of these three showed significant precipitation with the paratoluene sulphonic acid test, but two gave a + reaction (Table II).

\section{TABLE II}

RESULTS OF PARATOLUENE SULPHONIC ACID TESTS ON 812 PATIENTS WITH CONDITIONS OTHER THAN PROVED SYSTEMIC LUPUS ERYTHEMATOSUS

\begin{tabular}{|c|c|c|c|c|c|c|c|}
\hline \multirow{2}{*}{ Disease } & & \multirow{2}{*}{$\begin{array}{c}\text { No. of } \\
\text { Patients } \\
\text { Tested }\end{array}$} & \multicolumn{5}{|c|}{ Paratoluene Sulphonic Acid Test } \\
\hline & & & $\mathbf{0}$ & \pm & + & ++ & +++ \\
\hline $\begin{array}{l}\text { PS.L.E. } \\
\text { Discoid L.E. } \\
\text { Others } \quad \text {. }\end{array}$ & 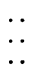 & $\begin{array}{r}3 \\
51 \\
758\end{array}$ & $\begin{array}{r}1 \\
44 \\
596\end{array}$ & $\overline{61}$ & $\begin{array}{r}2 \\
6 \\
59\end{array}$ & $\overline{28}$ & $\overline{\overline{14}}$ \\
\hline Total & . & 812 & 641 & 62 & 67 & 28 & 14 \\
\hline
\end{tabular}

Discoid Lupus Erythematosus-All the 51 patients in this group had been diagnosed by an experienced dermatologist. Eight showed minor evidence of some systemic upset such as Raynaud's phenomenon, arthralgia, lymphadenopathy, an accelerated blood sedimentation rate, leucopenia, or serum protein abnormalities. All had negative L.E. tests on one or more occasions. None of the 51 sera from these patients showed significant precipitation, but seven showed a light precipitate (either \pm or + , Table II).

Other Diseases and Normal Subjects-Serum from 758 other subjects was tested. This included 38 healthy blood donors, 36 normal pregnant women, and 684 ward or clinic patients. The diagnosis in these cases was obtained from the 


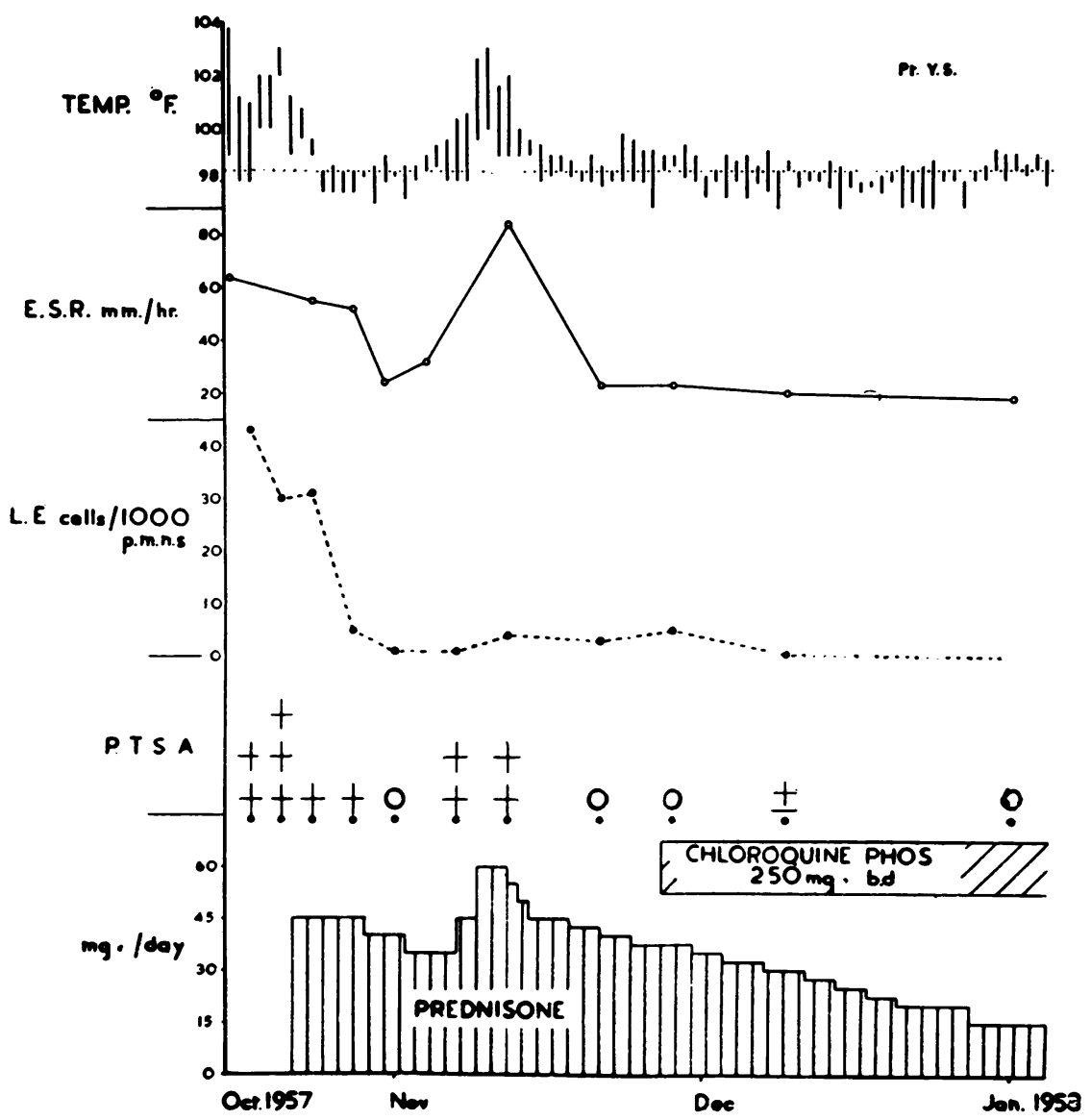

FIG. 2.-Effect of steroid treatment on paratoluene sulphonic acid test result. The test results are graded as in Fig. 1, and are shown in the chart as a dot with the result read vertically above.

hospital case notes or in some cases from personal examinations. Many patients had multiple tests.

Serum from 42 of these patients gave significant precipitation (Table III), but minor degrees of precipitation were encountered in no less than 129 others. The remaining patients gave negative test results.

Almost half of the positive tests in this group were associated with obstructive or hepatocellular jaundice and the remainder included a high proportion with diseases of the reticulo-endothelial system, others with syphilis, rheumatoid arthritis, and in one case with ankylosing spondylitis with peripheral joint involvement. In view of the alleged occurrence of L.E. cells in drug reactions, it is of interest that the only patient with a drug reaction in this series did have a positive paratoluene sulphonic acid test. The L.E. test on this patient was negative.
TABLE III

PATIENTS WITH DISEASES OTHER THAN SYSTEMIC LUPUS ER YTHEMATOSUS SHOWING SIGNIFICANT $(++\mathrm{OR}+++)$ PRECIPITATION WITH PARATOLUENE SULPHONIC ACID REAGENT

\begin{tabular}{|c|c|c|c|}
\hline Diagnosis & & \begin{tabular}{|c|} 
No. of Patients \\
with Positive Test
\end{tabular} & $\begin{array}{l}\text { No. of Patients } \\
\text { Tested }\end{array}$ \\
\hline $\begin{array}{l}\text { Cirrhosis } \\
\text { Infective hepatitis } \\
\text { Obstructive jaundice } \ldots\end{array}$ & $\begin{array}{l}\cdots \\
\cdots\end{array}$ & $\begin{array}{r}11 \\
2 \\
6\end{array}$ & $\begin{array}{r}36 \\
4 \\
11\end{array}$ \\
\hline $\begin{array}{l}\text { Rheumatoid arthritis } \\
\text { Ankylosing spondylitis }\end{array}$ & $\begin{array}{l}\cdots \\
\cdots\end{array}$ & $\begin{array}{l}4 \\
1\end{array}$ & $\begin{array}{r}46 \\
8\end{array}$ \\
\hline $\begin{array}{l}\text { Myelomatosis } \\
\text { Sarcoidosis } \\
\text { Lymphoma or leukaemia } \\
\text { Late syphilis } \\
\text { Penicillin sensitivity } \ldots \\
\text { Miscellaneous conditions }\end{array}$ & $\begin{array}{l}\cdots \\
\cdots \\
\cdots \\
\cdots\end{array}$ & $\begin{array}{l}2 \\
1 \\
2 \\
3 \\
1 \\
9\end{array}$ & $\begin{array}{r}3 \\
2 \\
7 \\
20 \\
1 \\
620\end{array}$ \\
\hline Total & $\ldots$ & 42 & 758 \\
\hline
\end{tabular}

In none of these 42 patients with positive tests was the clinical picture suggestive of systemic lupus erythematosus and in 30 cases L.E. tests 
on the same samples of blood as were used for the paratoluene sulphonic acid tests proved negative.

Nature of the Precipitate.-The precipitates produced from nine positive sera (four from patients with systemic lupus erythematosus and five from patients with other conditions) were washed twice with distilled water, smeared on filter paper and dried. In every case the precipitate stained intensely with light green dye and weakly with Sudan black, indicating a considerable protein content with a little lipoprotein.

The precipitate was invariably insoluble in distilled water but moderately soluble in normal sodium hydroxide. Unfortunately, the resulting solution, when neutralized, showed no electrophoretic mobility, presumably because the protein had been denatured.

Scrutiny of the serum protein electrophoretic patterns, however, did suggest that the patients with a strongly positive paratoluene sulphonic acid test had high serum $\gamma$ globulin levels. The absolute amount of serum $\gamma$ globulin was therefore estimated on 24 sera and correlated with the paratoluene sulphonic acid result. The $\gamma$ globulin was estimated from the total serum proteins as measured by the biuret method, and from the scanning of the paper electrophoretic pattern.

It can be seen from Table IV that, while there was considerable overlap between groups, the

TABLE IV

SERUM $\gamma$ GLOBULIN VALUES CORRELATED WITH RESULTS OF PARATOLUENE SULPHONIC ACID TESTS ON THE SAME SERA

\begin{tabular}{|c|c|c|c|c|}
\hline $\begin{array}{l}\text { Paratoluene } \\
\text { Sulphonic Acid } \\
\text { Test Result }\end{array}$ & o & \pm or + & ++ & +++ \\
\hline 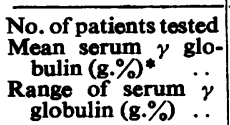 & $\begin{array}{c}5 \\
1.36 \\
1.2-1.6\end{array}$ & $\begin{array}{c}6 \\
1.81 \\
1 \cdot 1-2 \cdot 7\end{array}$ & $\begin{array}{c}7 \\
2 \cdot 2 \\
1 \cdot 3-2 \cdot 5\end{array}$ & $\begin{array}{c}6 \\
2 \cdot 8 \\
1.4-4.0\end{array}$ \\
\hline
\end{tabular}

* Analysis of variance on the original $\gamma$ globulin values showed a difference between groups significant at the $5 \%$ level.

mean serum $\gamma$ globulin of each group did increase consistently with the intensity of precipitation produced by paratoluene sulphonic acid, suggesting that the latter may be precipitating $\gamma$ globulin.

This was confirmed on $25 \mathrm{ml}$. of pooled serum from two patients with systemic lupus erythematosus by using ether fractionation to separate various protein fractions. $\dagger$ The freeze-dried protein fractions along with a freeze-dried sample of the original serum were then reconstituted in half the

+ This was done by Dr. R. A. Kekwick at the Lister Institute of Preventive Medicine, using the technique of Kekwick and MacKay (1954).
TABLE V

RESULTS OF PARATOLUENE SULPHONIC ACID TESTS ON PROTEIN FRACTIONS OF POOLED SYSTEMIC LUPUS ERYTHEMATOSUS SERUM

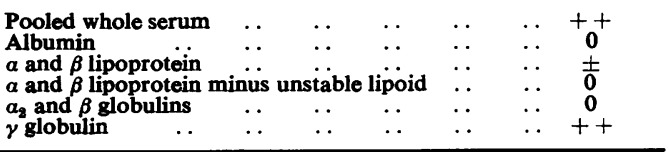

theoretical volume of distilled water to allow for wastage, and tested with the paratoluene sulphonic acid reagent (Table V). Only the whole serum and the $\gamma$ globulin fraction gave positive results. The latter fraction was checked by paper electrophoresis and found to consist almost wholly of $\gamma$ globulin with a mere trace of $\beta$ globulin. This fraction contained no lipoprotein, so it seems likely that the trace of lipoprotein found in the analysis of precipitate from whole serum had been adsorbed during precipitation.

A solution of $\gamma$ globulin prepared by ether fractionation of pooled normal sera (obtained from the Lister Institute of Preventive Medicine) gave a positive paratoluene sulphonic acid test, the intensity being proportional to the concentration of $\gamma$ globulin. Significant precipitation occurred with solutions containing $4 \%$ or more of $\gamma$ globulin.

Since the paratoluene sulphonic acid reagent precipitates $\gamma$ globulin from sera of normal people and of patients with various diseases, it seems likely that the test is related to an increased quantity of $\gamma$ globulin or some fraction thereof, rather than to an abnormal $\gamma$ globulin fraction.

\section{Discussion}

It is obvious that the paratoluene sulphonic acid test cannot be used alone to support a diagnosis of systemic lupus erythematosus and that the more specific L.E. cells must be sought in all suspected cases. Even as a screening test the paratoluene sulphonic acid precipitation is not ideal because of the occasional negative results in florid untreated systemic lupus erythematosus. It is of interest that the one striking example of this (patient K. O. in Table I) had a severe nephrotic syndrome with massive proteinuria and low total serum proteins with a serum $\gamma$ globulin of only $1.2 \mathrm{~g}$. per $100 \mathrm{ml}$.

However, because of its simplicity, the test may prove useful provided that a positive result is interpreted as indicating a raised serum $\gamma$ globulin component which may be due to systemic lupus erythematosus as well as other diseases.

Although in untreated cases of systemic lupus erythematosus the paratoluene sulphonic acid test 
does seem to parallel the severity of the illness, this association is not always present after steroid therapy. The erythrocyte sedimentation rate will then prove a more reliable guide to the activity and progress of the disease.

\section{Summary}

A simple serum protein precipitation test, using paratoluene sulphonic acid in glacial acetic acid, has been examined for its value in the diagnosis of systemic lupus erythematosus. A positive test was found to depend upon an excess of serum $\gamma$ globulin.

Thus it was positive in the majority of cases of untreated active systemic lupus erythematosus and negative in all cases of discoid lupus erythema- tosus. It was positive, however, in a number of conditions other than systemic lupus erythematosus which were associated with a raised serum $\gamma$ globulin level.

With the exception of rheumatoid arthritis, these other conditions were generally readily distinguishable from systemic lupus erythematosus on clinical grounds.

We wish to thank Dr. A. B. Anderson for providing facilities for much of this work and Dr. R. A. Kekwick for his help with the protein fractionation.

\section{REFERENCES}

Jones, K. K., and Thompson, H. E. (1957). 9th International Congress on Rheumatic Diseases. Toronto.

Kekwick, R. A., and MacKay, M. E. (1954). Spec. Rep. Ser. med. Res. Coun. (Lond.), No. 286. 